\title{
The ethylene biosynthetic and signal transduction pathways are differently affected by 1-MCP in apple and peach fruit
}

\author{
Valeriano Dal Cin, Fabio Massimo Rizzini, Alessandro Botton, Pietro Tonutti* \\ Department of Environmental Agronomy and Crop Science, University of Padova, Viale dell'Università 16, 35020 Legnaro, Padova, Italy
}

Received 4 February 2006; accepted 21 June 2006

\begin{abstract}
1-Methylcyclopropene (1-MCP) is an antagonist of ethylene for receptor binding sites and the effects of its application differ in relation to a number of factors including genotype and ripening physiology. Peach (Prunus persica L. Batsch cv. 'Summer Rich') and apple (Malus $\times$ domestica L. Borkh cv. 'Golden Delicious') fruits were incubated with 1-MCP $\left(1 \mu \mathrm{LL}^{-1}\right)$ for $24 \mathrm{~h}$ at $20^{\circ} \mathrm{C}$ and respiration rate, ethylene production and fruit firmness, together with ACC synthase, ACC oxidase, ETR1, ERS1, and CTR1 gene expression patterns were assessed throughout the post-treatment phase. 1-MCP was confirmed to be effective in delaying ripening in apples while in peaches only a limited effect of the chemical was observed. A dramatic inhibition of ethylene biosynthesis and ACS gene expression was induced by 1-MCP in apples whereas no marked difference was observed in peaches between the two controls (in air and in sealed jars without 1-MCP) and the treated fruit. In apples, Md-ETR1 and Md-ERS1 gene expression was down-regulated by 1-MCP starting from the end of the treatment, while $M d$-CTR1 appeared negatively affected by the chemical at a later stage. Transcription of Pp-ETR1, Pp-ERS1 and Pp-CTR1 genes appeared unaffected in 1-MCP treated peaches. Differences in receptor transcript levels between control fruit maintained in air and those enclosed in sealed jars without 1-MCP may be due to an effect of $\mathrm{CO}_{2}$ that rapidly accumulates following incubation of ripening peaches. Results support the hypothesis that the different behaviour of peaches and apples in response to 1-MCP application might be related to differences in terms of ratio, expression patterns and/or turn-over of the ethylene receptors.
\end{abstract}

(C) 2006 Elsevier B.V. All rights reserved.

Keywords: Carbon dioxide; ERS; ETR; Ethylene receptors; Postharvest; Ripening

\section{Introduction}

Following the elucidation of the biosynthetic pathway of ethylene and, more recently, the identification of some elements involved in its perception and signal transduction, a better understanding of the role of ethylene and the mechanisms of its action has been achieved. Genes encoding 1-aminocyclopropane-carboxylase (ACC) synthase (ACS) and ACC oxidase (ACO), the two key enzymes catalyzing the last steps of the biosynthetic pathway, have been isolated and extensively studied not only in tomato, the model species for fruit ripening studies, but also in other fruit types including peaches (Prunus persica L. Batsch) (Tonutti et al., 1997; Mathooko et al., 2001; Ruperti et al., 2001) and apples (Malus $\times$ domestica L. Borkh) (Rosenfield et al.,

\footnotetext{
* Corresponding author. Tel.: +39049 8272845; fax: +390498272850.

E-mail address: pietro.tonutti@unipd.it (P. Tonutti).
}

1996; Atkinson et al., 1998; Sunako et al., 1999). Despite the differences in terms of ripening physiology such as the respiration climacteric, in both apples and peaches the ethylene climacteric at ripening is accompanied by increases in ACS and ACO transcript accumulation and the genes involved are induced by ethylene and participate in the autocatalytic synthesis of the hormone.

The ethylene signal transduction pathway has been primarily studied in Arabidopsis where five functional ethylene receptors have been identified (Chang and Stadler, 2001). They show similarity to bacterial two-component histidine kinase sensors and function as negative regulators of ethylene responses (Chang and Stadler, 2001). With regard to fruit species, six ethylene receptors have been isolated and characterized in tomato (reviewed in Bleecker, 1999) where the overall receptor RNA level appears to be much higher in ripening fruit than in immature fruit (Lashbrook et al., 1998; Tieman and Klee, 1999). Ethylene receptors have been 
studied in other fruit species including peach. Specific analyses of the two isolated peach ethylene receptors showed different patterns of expression at ripening and following exogenous propylene (an ethylene analog) treatments (Rasori et al., 2002). In apple, two ethylene receptors have been isolated and their sequences are available in the public database. Data concerning their expression patterns are available only for during early fruit development and abscission (Dal Cin et al., 2005a).

CTR1, a key negative regulator of ethylene responses (Kieber et al., 1993), acts downstream from the ethylene receptors. The N-terminal domain of CTR1 appears to be associated with the histidine kinase domains of ETR1 and ERS1 and its function may be regulated by its association/dissociation with the ethylene receptors (Huang et al., 2003). In Arabidopsis, At-CTRl is constitutively expressed (Kieber et al., 1993), whereas in tomato, Le-CTRl is upregulated by ethylene during fruit ripening (Leclercq et al., 2002). More recently, it has been demonstrated that a multigene family of functional $C T R l$ genes is present in tomato and is differentially regulated by ethylene during stages of development characterized by increases in ethylene biosynthesis (Adams-Phillips et al., 2004). Apart from pears (El-Sharkawy et al., 2002) and apples (Dal Cin et al., 2005a), no information on $C T R$ genes is so far available in other fruit of Rosaceae species.

The possibility of controlling the ripening process and extending the shelf-life is a primary goal in the fruit industry and one tool is represented, in climacteric fruit, by the use of inhibitors of ethylene action. Affecting the transduction pathway from the first step (i.e. the receptors) appears to be a highly effective way to modulate responses to ethylene. 1Methylcyclopropene (1-MCP), a powerful antagonist of ethylene for receptor binding sites, has been recently proposed to prolong shelf-life and delay ripening in the postharvest phase (Sisler and Serek, 1997). The effects of 1-MCP application on the development of ripening parameters differ, however, in relation to a number of endogenous and exogenous factors including genotype and ripening stage (Blankenship and Dole, 2003). Different effects of 1-MCP are particularly evident when comparing two important crops such as apples and peaches: ripening is inhibited or delayed for many days and storage prolonged in apples (Fan and Mattheis, 2002; Watkins et al., 2000; Jiang and Joyce, 2002; Bai et al., 2005). On the other hand, 1-MCP appears to have limited effects on slowing ripening of peaches and nectarines, in which ethylene production is not inhibited (Mathooko et al., 2001; Fan et al., 2002; Ziliotto et al., 2003). Since peaches, differently from apples, are characterized by moderately high respiration rates at ripening, when evaluating the effect of 1-MCP, particular care should be taken with regard to $\mathrm{CO}_{2}$ accumulation in the jars sealed for a treatment period lasting, in general, $12-24 \mathrm{~h}$. In fact, when ripening peaches are incubated, $\mathrm{CO}_{2}$ quickly accumulates in the jars (in particular if the mass/volume ratio is high) reaching elevated concentrations, effective in influencing physiological processes. In tomato, high $\mathrm{CO}_{2}$ induces the expression of stress-related genes and suppresses the transcription of ethylene-dependent and ethylene-independent ripening-associated genes (Rothan et al., 1997). The effects of concentrations as low as $3.5 \%$ or higher on prolonging peach postharvest life have been described (Kader, 1985; Bonghi et al., 1999). Using a continuous flow-through gas system, it has been demonstrated that $20 \% \mathrm{CO}_{2}$ markedly decreases ethylene biosynthesis in ripening peaches by delaying and suppressing ACC synthase at the transcriptional level and that a recovery of these parameters occurs upon withdrawal of $\mathrm{CO}_{2}$ (Mathooko et al., 2001).

In order to ascertain if the dissimilar behaviour of peaches and apples to postharvest 1-MCP treatments is a consequence of a different sensitivity to ethylene and/or of a selective ability to regenerate receptors, comparative data on ethylene biosynthesis, ETR, ERS and CTR gene expression following 1-MCP treatments and, only for peaches, in relation to $\mathrm{CO}_{2}$ accumulation, are reported herein.

\section{Materials and methods}

\subsection{Plant material and treatments}

Peach (Prunus persica L. Batsch, cv. Summer Rich) and apple (Malus $\times$ domestica L. Borkh. cv. Golden Delicious) fruits were harvested at a stage equivalent to commercial ripeness and immediately transferred to the Postharvest Laboratory of the Faculty of Agriculture, University of Padova, Italy, where they were maintained at room temperature (around $20^{\circ} \mathrm{C}$ ) throughout the experiments. Fruits were selected and measurements of flesh firmness, ethylene production and respiration (see below) were performed. Fruits were divided into two bunches: one group was enclosed in gas-tight glass jars $\left(\sim 80 \mathrm{~kg} \mathrm{~m}^{-3}\right.$ for both apples and peaches) and treated for $24 \mathrm{~h}$ with $1 \mu \mathrm{LL}^{-1}$ of 1-MCP while the second group was left on the bench (open control).

In a preliminary experiment we had noticed that, after incubation for $24 \mathrm{~h}$ at $20^{\circ} \mathrm{C}$ in sealed jar (at the same mass/volume ratio), $\mathrm{CO}_{2}$ accumulated to values of about 8 and $1 \%$ for peaches and apples, respectively. Thus, in order to avoid excessive $\mathrm{CO}_{2}$ accumulation, jars containing peaches were opened every $8 \mathrm{~h}$, flushed with air, and the 1-MCP concentration re-established. Considering that at the end of each $8 \mathrm{~h}$ incubation period $\mathrm{CO}_{2}$ reached values of about $1.5 \%$, an additional control consisting of peaches enclosed in jars with no $1-\mathrm{MCP}$ and opened every $8 \mathrm{~h}$ was included (sealed control). After the $24 \mathrm{~h}$ incubation period, all sealed fruits were transferred to air.

Flesh firmness (penetrometer TR, Forlì, Italy, using 6 and $8 \mathrm{~mm}$ probes for peaches and apples, respectively), ethylene production (gas chromatograph DANI 3200) and respiration (Oxycarb 5, Isolcell Italia Spa, Laives-Bolzano, Italy) were monitored throughout the experiment. These measurements were performed on at least three (firmness) and ten (ethylene and respiration) fruit for each treatment and sampling 
Table 1

Deduced amino acid identity (\%) of apple $M d$-CTR1 and peach $P p$-CTR1 isolated fragments (about $600 \mathrm{bp}$ ) with the corresponding regions of CTR sequences of tomato (Le-CTR1, Le-CTR3, Le-CTR4), Arabidopsis (At-CTRl), and rose (Rh-CTRl)

\begin{tabular}{|c|c|c|c|c|c|c|c|}
\hline Gene & $\begin{array}{l}\text { Le-CTR1, } \\
\text { AY394002 (\%) }\end{array}$ & $\begin{array}{l}\text { Le-CTR3, } \\
\text { AY382676 (\%) }\end{array}$ & $\begin{array}{l}\text { Le-CTR4, } \\
\text { AY382678 (\%) }\end{array}$ & $\begin{array}{l}\text { At-CTR1, } \\
\text { AY075618 (\%) }\end{array}$ & $\begin{array}{l}\text { Rh-CTR1, } \\
\text { AY032953 (\%) }\end{array}$ & $\begin{array}{l}\text { Md-CTR1, } \\
\text { AY670703 (\%) }\end{array}$ & $\begin{array}{l}\text { Pp-CTR } 1, \\
\text { AY945799 (\%) }\end{array}$ \\
\hline Md-CTR1 & 91.3 & 92.7 & 91.3 & 91.7 & 91.2 & - & 93.6 \\
\hline Pp-CTR1 & 90.8 & 93.2 & 90.8 & 92.7 & 93.6 & 93.6 & - \\
\hline
\end{tabular}

date. Peach mesocarp and apple cortex tissues from at least two fruit displaying similar ethylene production and firmness values comparable with the mean of the specific sample were frozen in liquid nitrogen and stored at $-80^{\circ} \mathrm{C}$.

\subsection{RNA extraction and northern analyses}

Total RNA was obtained following the protocol described by Ruperti et al. (2001) with slight modification as reported by Dal Cin et al. (2005b). For northern analyses, $10 \mu \mathrm{g}$ of total RNA was loaded on a $1 \%$ denaturing gel, blotted, hybridized with specific ${ }^{32} \mathrm{P}$ labelled probes and exposed to X-ray films as described by Tonutti et al. (1997). Specific probes used in northern analyses were Pp-ACOl (Ruperti et al., 2001) and a $500 \mathrm{bp} M d$ $A C O$ fragment obtained after amplification with specific primers (F: 5-GAAGCTTTTGGACTTGCTGTGTGA-3; R: 5-AAATCTTGGCTCCTTGGCTTGGA-3) of ripe apple cDNA using 0.025 U/ $\mu \mathrm{L}$ Taq-polymerase (AmpliTaq-Gold, Applied Biosystems, Branchburg, NJ). Reaction parameters were: $10 \mathrm{~min}$ at $95^{\circ} \mathrm{C}$, and then 40 cycles and $1 \mathrm{~min}$ at $72^{\circ} \mathrm{C}$. Each cycle included denaturation at $94{ }^{\circ} \mathrm{C}$ for $30 \mathrm{~s}$, annealing at $62^{\circ} \mathrm{C}$ for $30 \mathrm{~s}$ and extension at $72{ }^{\circ} \mathrm{C}$ for $30 \mathrm{~s}$. RNA loading was checked by hybridization with rRNA $18 \mathrm{~S}$.

\section{3. cDNA synthesis and isolation of CTR1-like sequences of apple and peach}

cDNAs from apple and peach RNA samples were synthesized as follows: $30 \mu \mathrm{g}$ of total RNA were treated with 10 units of RQ1 RNase-Free DNAse (Promega) and 1 unit of RNAguard (RNase INHIBITOR) (Amersham) for $30 \mathrm{~min}$, then purified by phenol-chlorophorm. A $1 \mu \mathrm{g}$ of total RNA DNA-free was reverse-transcribed with 200 units of MMLV Reverse Transcriptase (Promega), 1 unit of RNAguard (RNase INHIBITOR) and $2.5 \mu \mathrm{M}$ oligo-d $\mathrm{d}_{12-18}$ as primer at $37^{\circ} \mathrm{C}$ for $90 \mathrm{~min}$ in a final volume of $20 \mu \mathrm{L}$, as described in Sambrook et al. (1989).

Apple and peach CTR1 partial cloning was performed via PCR using primers designed from conserved sequence motifs of sequenced CTR1 genes (WNGSDVAV and LEIPRDL) with $1 \mu \mathrm{L}$ of cDNA obtained from cortex and mesocarp of apple and peach, respectively. The primers were as follow: F:-5-GGMATGGMWCWGAKGTTGCTGT-3; R: 5CAAATCACGTGGAATCTCAAG-3. Reactions were carried out with the Gene Amp PCR system 9700 (Applied Biosystems, Branchburg, NJ) using $0.025 \mathrm{U} / \mu \mathrm{L}$ Taqpolymerase (Amersham Biosciences, Piscataway, NJ) under the following conditions: $5 \mathrm{~min}$ at $94^{\circ} \mathrm{C}$ followed by 40 cycles of $1 \mathrm{~min}$ at $94^{\circ} \mathrm{C}, 1.5 \mathrm{~min}$ at $57^{\circ} \mathrm{C}, 1 \mathrm{~min}$ at $72^{\circ} \mathrm{C}$, and $7 \mathrm{~min}$ of final extension at $72^{\circ} \mathrm{C}$.

The amplification products of about $600 \mathrm{bp}$ were subcloned into pGEM-T Easy vector (Promega, Milan, Italy) and five plasmids from recombinant colonies were sequenced using both SP6 and T7 primers by CRIBI laboratory (University of Padova, Italy). Deduced amino acid sequences comparison was performed using Clustal $\mathrm{V}$ algorithm with default parameters. Identity levels of peach Pp-CTRI and apple $M d$-CTR 1 with CTR sequences of tomato, Arabidopsis and rose are reported in Table 1.

\subsection{Quantification of $m R N A$ via $R T-P C R$}

Transcript accumulation of Md-ETR1 (AF032448), Pp-ETRI (AF396830), Md-ERS (AY083169), Pp-ERS1 (AY061640), Md-CTR1 (AY670703), Pp-CTR1 (AY945799), Md-ACS1 (U89156) and Pp-ACS (AB044662) was evaluated via quantitative RT-PCR using the SYBR Green RT-PCR master mix kit (PE Applied Biosystem) as described by Cecchetti et al. (2004). For each sample, three replicates were performed in a final volume of $50 \mu \mathrm{L}$ containing $1 \mu \mathrm{L}$ of the cDNA single strand obtained as previously described, $15 \mathrm{pmol}$ of specific primers and $25 \mu \mathrm{L}$ of $2 \times$ SYBR Green PCR Master mix according to the manufacturer's instructions. The standard gene was r18S (Rasori et al., 2002). Specific primers were as reported in Table 2. Reaction parameters were: $10 \mathrm{~min}$ at $95^{\circ} \mathrm{C}$, and then 40 cycles and $1 \mathrm{~min}$ at $72^{\circ} \mathrm{C}$. Each cycle included denaturation at $94{ }^{\circ} \mathrm{C}$ for $30 \mathrm{~s}$, annealing at $64{ }^{\circ} \mathrm{C}$ for $30 \mathrm{~s}$ and extension at $72^{\circ} \mathrm{C}$ for $30 \mathrm{~s}$.

The amount of specific transcripts was calculated following the comparative $\mathrm{C}_{\mathrm{T}}$ method (Kenneth and Thomas, 2001). In brief, the amplification plot obtained at the end of the PCR reaction was evaluated and a threshold corresponding to the exponential phase was fixed. The intersection between this threshold and the amplification curve allowed the identification of a point located to the cycle axis. This value was compared to the value of the internal standard and used in the formula $\left(=2^{-\Delta \mathrm{CT}}\right)$ to obtain the expression level.

\section{Results}

After incubation with 1-MCP for $24 \mathrm{~h}$, firmness values did not differ between control and treated apples for up to 7 days when control fruit started showing a significantly 
Table 2

Specific primers used in RT-PCR mRNA quantification (F: forward; R: reverse)

\begin{tabular}{lll}
\hline Gene & Primer F & Primer R \\
\hline$r 18 S$ & 5-GTTACTTTTAGGACTCCGCC-3 & 5-TTCCTTTAAGTTTCAGCCTTG-3 \\
$M d-E T R 1$ & 5-TTGGCCTGTGAAGAGCAGT-3 & 5-TGCAAACCATGTAGAGCCAT-3 \\
$P p$ - $E T R 1$ & 5-ATGATAACGGGTCAGTGACT-3 & 5-AAATAACGTGCAAGAACTCATC-3 \\
$M d-E R S$ & 5-CAACTAGGGATATGCGAC-3 & 5-CACTGGCATCCAAAGACTTC-3 \\
$P p$ - $E R S 1$ & 5-GATTGAGAGTGAGGGCATTG-3 & 5-GCTGCTGTTGTATCACAAGG-3 \\
$M d-C T R 1$ & 5-ACAAGATTTTCATGCCGAAC-3 & 5-TATGGACAAGTTTGGAGGCT-3 \\
$P p$ - $C T R 1$ & 5-GCAAGACTTTCATGCCGAAC-3 & 5- TATGGACAAGTTTGGGGGCT -3 \\
$M d-A C S 1$ & 5-CTGGACTTGGCAATGCAGA-3 & 5-CGGGAAACCCACTTTGTGA-3 \\
$P p-A C S$ & 5-CAAAACATGAATTGCAACCC-3 & 5-ACCCGAAACTTGACATCTTG-3 \\
\hline
\end{tabular}

faster decrease of this property (Fig. 1A). 1-MCP treated fruit remained firmer throughout the experimental period (37 days). Respiration was significantly reduced in treated fruit starting $8 \mathrm{~h}$ after the end of incubation and during the following day while control fruit were still displaying high rates of respiration (Fig. 1B). Ethylene production steadily increased from the beginning of the experiments and peaked in control fruit 12 days after harvest (Fig. 2A). The application of 1MCP dramatically affected the hormone production: in fact, ethylene biosynthesis remained undetectable from the end of the incubation period up to 12 days. The onset of ethylene production was observed only towards the end of the experiment (24 days after harvest) (Fig. 2A). ACS transcript accumula-
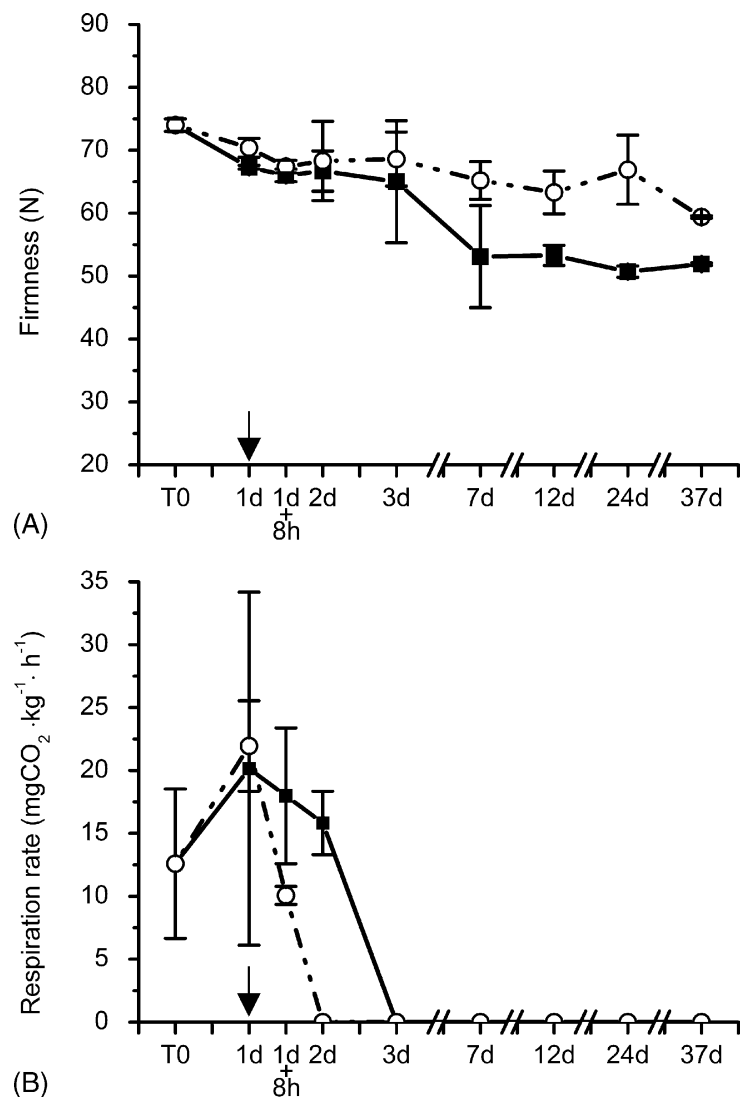

Fig. 1. Firmness (A) and respiration rate (B) in control (- - -) and 1-MCP treated $(\cdot \cdots \bigcirc \cdots-\cdot \cdot)$ 'Golden Delicious' apples. Arrows indicate the end of the incubation period. Vertical bars represent S.D. tion showed a steady increase throughout the experimental period in control apples, whereas a dramatic reduction, paralleling the kinetics of ethylene production, was observed in treated fruit (Fig. 2B). ACO gene expression was affected by 1-MCP in apples. A marked reduction of specific transcript
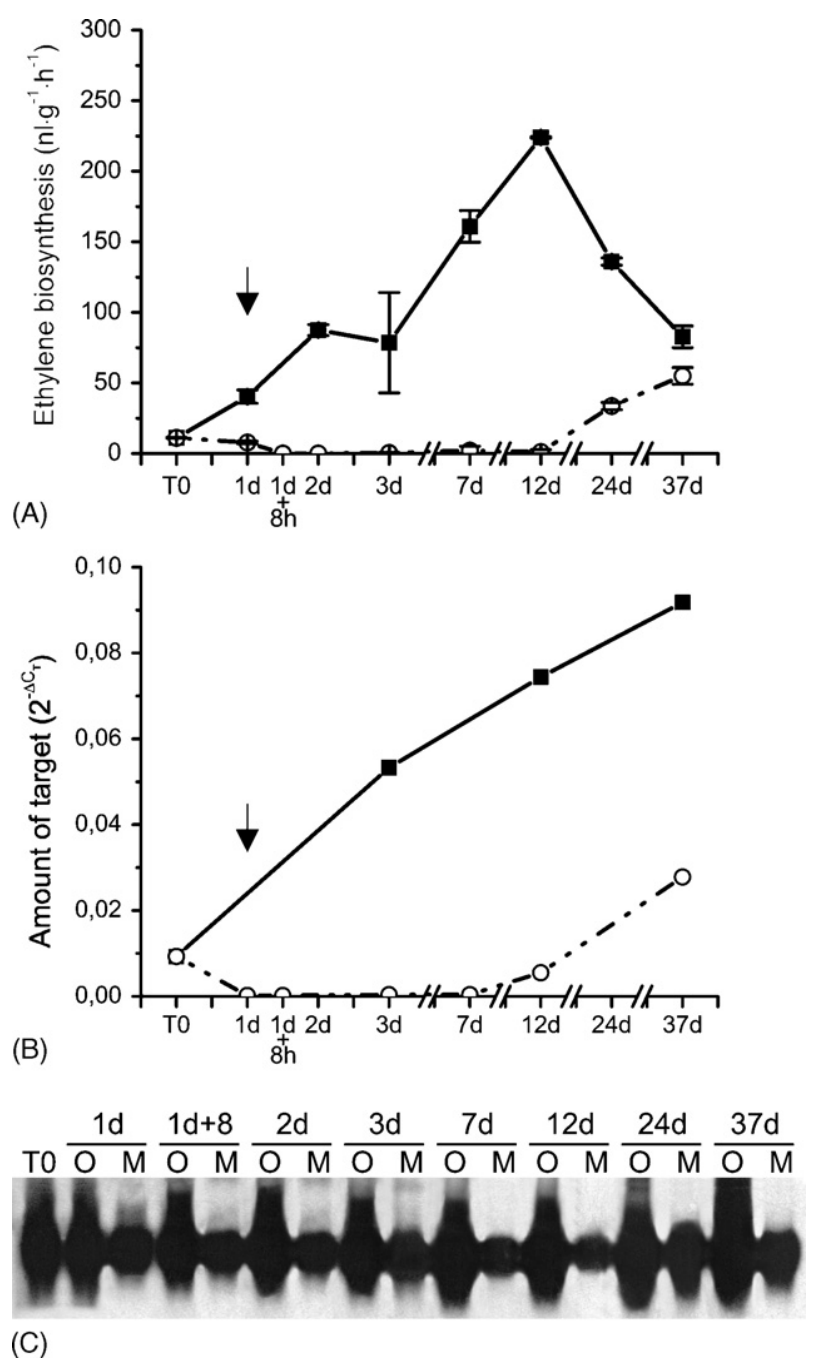

Fig. 2. Ethylene biosynthesis (A), and ACC synthase (B) and ACC oxidase (C) transcript accumulation, evaluated by real-time PCR and northern blotting, respectively, in control $(-\boldsymbol{-}-, \mathrm{O})$ and 1-MCP treated $(\cdots-\cdots \bigcirc \cdots-\cdot$, M) 'Golden Delicious' apples. Arrows indicate the end of the incubation period. Vertical bars represent S.D. 

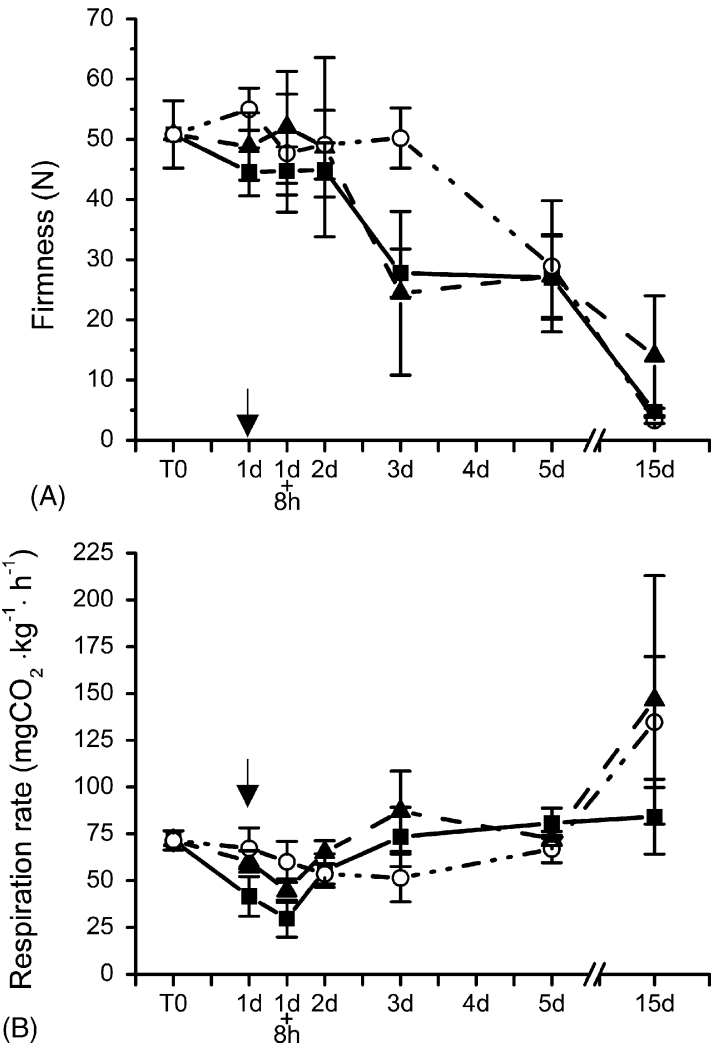

Fig. 3. Firmness (A) and respiration rate (B) in open control (- - ), sealed control (- - $\mathbf{\Delta}--)$ and 1-MCP treated $(.-\cdots \bigcirc \cdots-$.$) 'Summer Rich'$ peaches. Arrows indicate the end of the incubation period. Vertical bars represent S.D.

accumulation was detected in treated fruit starting from the end of the incubation period and throughout the experiment (Fig. 2C).

The application of 1-MCP to peaches confirmed the limited efficacy of the chemical on the fruit of this species. In fact, 1-MCP treated fruit were firmer than those of both controls (open and sealed) in correspondence of only one sampling date ( 3 days after the end of the incubation period). The melting process rapidly occurred thereafter and no difference was observed among samples (Fig. 3A). With the exception of the end of the treatment period and $8 \mathrm{~h}$ later, when 1-MCP treated fruit displayed higher rates, no significant differences were registered in terms of respiration rate (Fig. 3B). With regard to ethylene production, a similar trend was observed in control and 1-MCP treated fruit in which the climacteric peak occurred concomitantly with an advanced ripening stage (Fig. 4A). Small amounts of ethylene were produced from treated fruit $8 \mathrm{~h}$ after the end of the incubation period. After 3 days, ethylene was detectable in both controls but not in 1-MCP treated fruit. No difference was observed in the following sampling dates, even though higher values of ethylene biosynthesis were registered in treated fruit at the end of the experiment (Fig. 4A). Differently from apples, genes involved in the ethylene biosynthetic pathway were only slightly affected by $1-\mathrm{MCP}$ in peaches.
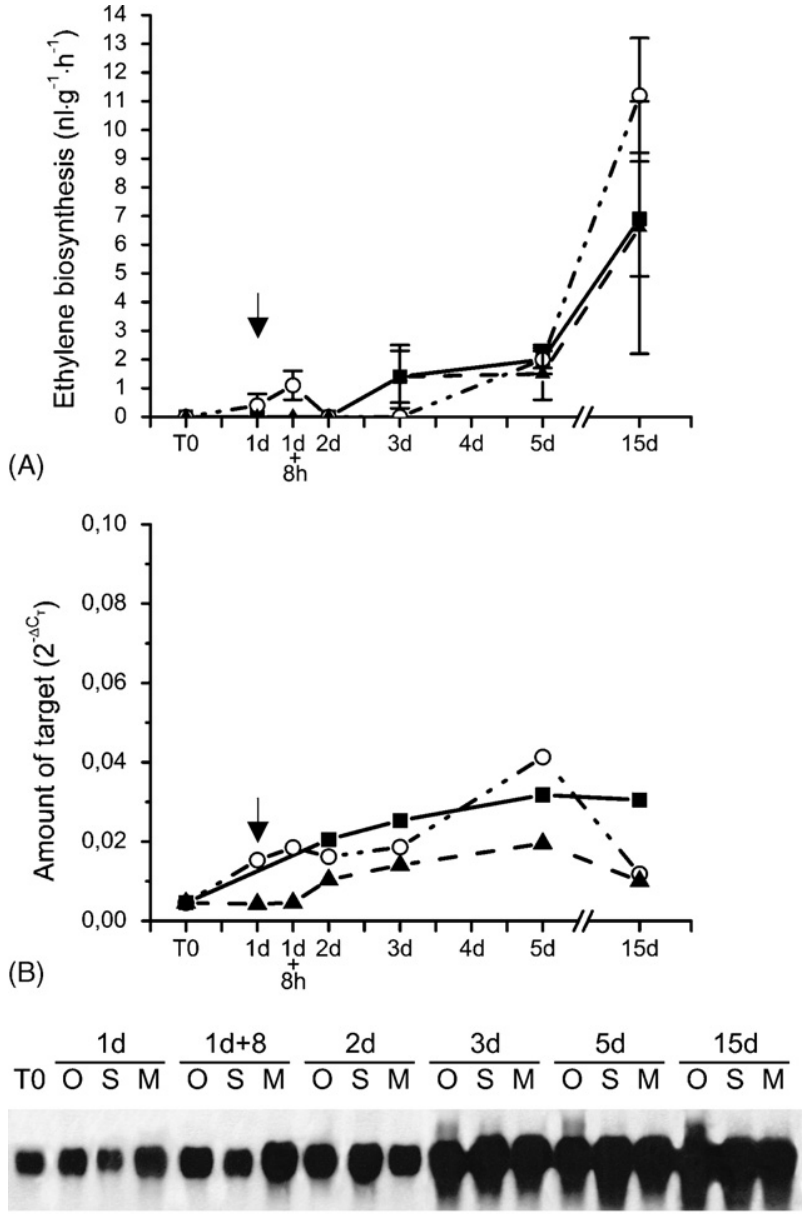

(C)

Fig. 4. Ethylene biosynthesis (A), ACC synthase (B), and ACC oxidase (C) transcript accumulation, evaluated by real-time PCR and northern blotting, respectively, in open control $(-\boldsymbol{\square}-, \mathrm{O})$, sealed control $(--\boldsymbol{\Delta}--, \mathrm{S})$ and 1MCP treated $(\cdots+\cdots \bigcirc \cdots-\cdots$, M) 'Summer Rich' peaches. Arrows indicate the end of the incubation period. Vertical bars represent S.D.

In general, $P p$-ACS mRNA accumulated at lower levels than Md-ACS1 (Figs. 2B and 4B). In open control fruit, ACS expression constantly increased throughout the experimental period, reaching the highest values at the time of the ethylene climacteric. Similar trends were observed in both sealed control and 1-MCP treated fruit, even though in the former, transcripts accumulated to a slightly lesser extent than in open control fruit, while in the latter, some increases at the end of the incubation period and 5 days from the beginning of the experiments were observed (Fig. 4B). ACO gene expression appeared unaffected by 1-MCP: in fact, no marked difference was observed among samples throughout the experimental period (Fig. 4C).

The ethylene transduction pathway of apples was strongly affected by 1-MCP. Considering the two isolated receptors, Md-ETRl transcripts constantly accumulated during the postharvest phase in control fruit (Fig. 5A). The ethylene inhibitor markedly affected this behaviour with a dramatic reduction of specific transcript accumulation, already evident 

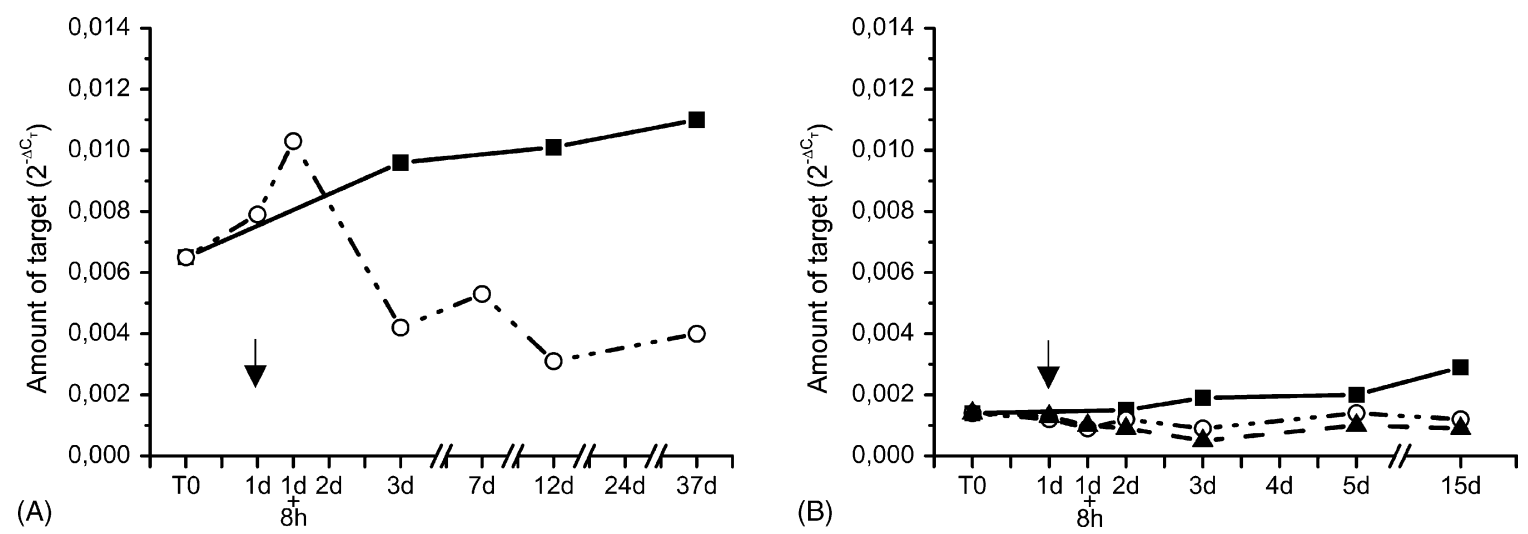

Fig. 5. Transcript accumulation, evaluated by real-time PCR, of: (A) Md-ETR1 in control (- - ) and 1-MCP treated $(\cdots-\cdots \bigcirc \cdots-\cdots)$ 'Golden Delicious'

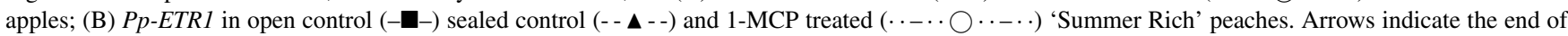
the incubation period.
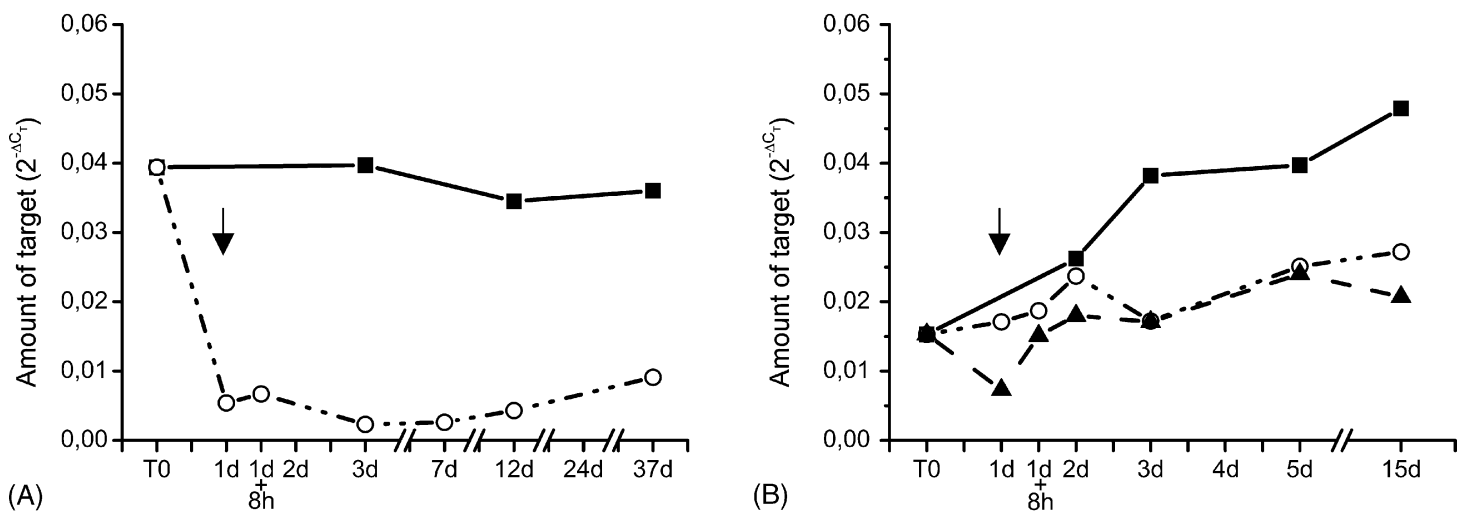

Fig. 6. Transcript accumulation, evaluated by real-time PCR, of: (A) Md-ERS1 in control (- - -) and 1-MCP treated $(\cdot \cdot-\cdot \bigcirc \cdots-\cdot \cdot)$ 'Golden Delicious' apples; (B) Pp-ERS1 in open control (- - -), sealed control (-- $\mathbf{\Lambda}--)$ and 1-MCP treated $(\cdot-\cdots \bigcirc \cdots-\cdot)$ 'Summer Rich' peaches. Arrows indicate the end of the incubation period.

a few hours after the end of the incubation period. Md-ERSI did not show significant changes in control fruit, whereas a dramatic and sudden decrease in specific transcript accumulation was detected at the end of the 1-MCP treatment and this low level was maintained throughout the experiment (Fig. 6A). In peach, Pp-ETRI transcript accumulation showed no significant changes in the experimental period between sealed control and 1-MCP treated fruit (Fig. 5B). A slight increase in specific transcript accumulation was only detected in open control samples at the last sampling date. No significant differences were observed between 1-MCP treated and sealed control fruit concerning Pp-ERS1 mRNA
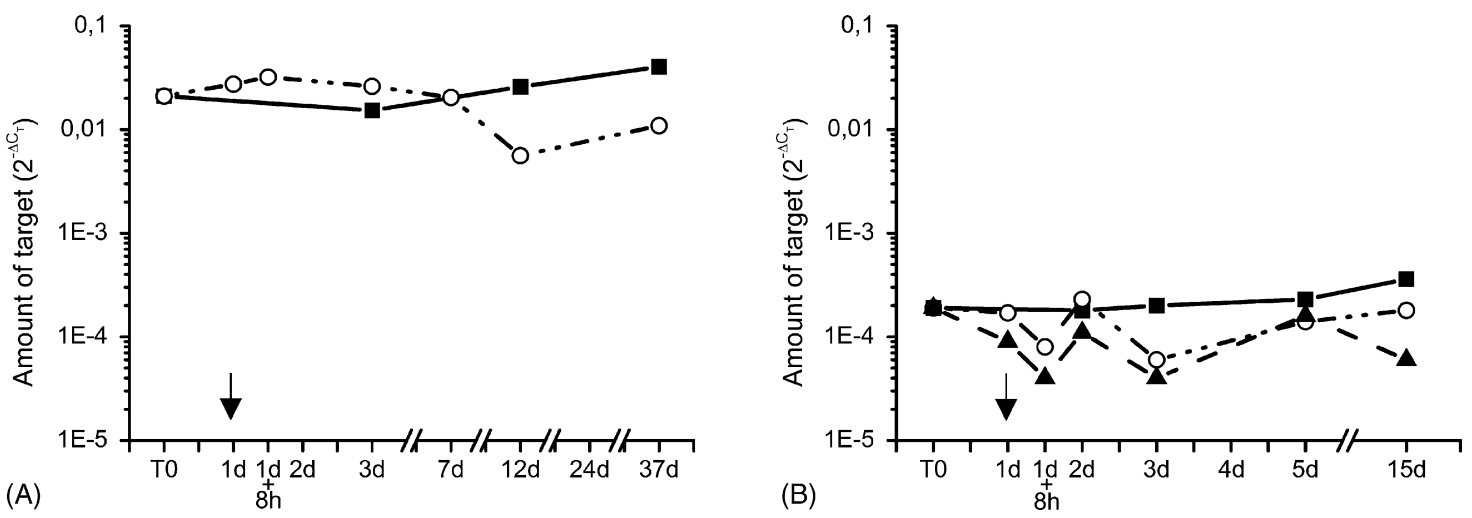

Fig. 7. Transcript accumulation, evaluated by real-time PCR, of: (A) Md-CTR1 in control (- - -) and 1-MCP treated ( . - . $\bigcirc \cdots-\cdot)$ 'Golden Delicious'

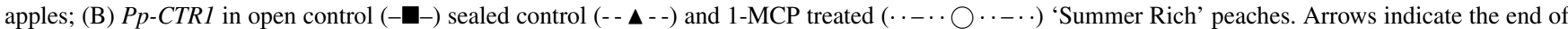
the incubation period. 
accumulation, which in general, remained quite stable during the experimental period (Fig. 6B). A steady increase in specific transcripts was instead detected throughout ripening in fruit of the open control.

Md-CTRl appeared to be constitutively expressed even though an increasing trend was observed in control fruit concurrently with the ethylene climacteric peak while a reduction, at the same sampling dates, was induced by 1MCP (Fig. 7A). Similarly to apples, Pp-CTRl showed an initial constitutive expression until the last sampling date when a slight increase of specific transcript accumulation was detected (Fig. 7B). The accumulation trend of Pp-CTRl transcript did not consistently differ between sealed control and 1-MCP treated fruit in which the level of specific transcripts appeared to be lower than that of open control fruit.

\section{Discussion}

In this paper the effects of 1-MCP on some ripening physiology parameters of peach and apple fruit have been compared. Results have highlighted the marked differences existing between these two fruit species in terms of ripening physiology and responses to the ethylene antagonist. Apples effectively react to 1-MCP treatments delaying ripening even at room temperature for several days, while trials on peaches confirmed that the effect of the ethylene action inhibitor on the maintenance of flesh firmness is limited to a few hours after the end of 1-MCP application. Some previously published papers have demonstrated a more prolonged effect of 1-MCP on peaches or nectarines but this might be imputed to the action of $\mathrm{CO}_{2}$ accumulated in the incubation jars rather than to a genuine effect of the ethylene inhibitor. Liguori et al. (2004) reported that, after maintaining peaches (150 fruit in $30 \mathrm{~L}$ ) at $20^{\circ} \mathrm{C}$ in sealed jars for a $5-20 \mathrm{~h}$ period, $\mathrm{CO}_{2}$ concentration reached values ranging from 6.7 to $19.4 \%$, respectively. It is well known that $\mathrm{CO}_{2}$ (even when applied for short periods) is effective in delaying ripening and reducing ethylene production in peaches (Bonghi et al., 1999; Mathooko et al., 2001). The limited effect of the ethylene action inhibitor on peaches was observed in a parallel trial following incubation with or without 1-MCP in jars containing also a $\mathrm{CO}_{2}$ absorber (unpublished data). Since under our experimental conditions ( $\sim 80 \mathrm{~kg}$ of fruit per $\mathrm{m}^{3}$ of incubation jar, temperature of $\sim 20^{\circ} \mathrm{C}$ ), $\mathrm{CO}_{2}$ concentrations easily reached values of about $8 \%$ after $24 \mathrm{~h}$ incubation, every $8 \mathrm{~h}$ jars were opened and flushed with air to avoid excessive $\mathrm{CO}_{2}$ accumulation and oxygen depletion. However, it must be noted that, in spite of jar opening at the end of each $8 \mathrm{~h}$ period, $\mathrm{CO}_{2}$ accumulated to values of about $1.5 \%$. This $\mathrm{CO}_{2}$ level was not effective in altering the ripening process as a whole. However, some differences in specific physiological parameters between open and sealed control fruit are present.

The role of ethylene synthesis and regulation in fruit development has been elucidated and the recent identification of elements involved in the ethylene signal pathway, defined primarily in Arabidopsis, offers new possibilities and tools to better understand mechanisms also participating in the developmental regulation of fruit ripening. Ethylene receptors function as negative regulators of ethylene responses and the hormone inactivates them (Bleecker and Kende, 2000). Genetic and biochemical studies using a number of mutants in Arabidopsis and tomato have shown that the receptors act redundantly to suppress ethylene responses in the absence of ethylene (Klee and Tieman, 2002). The increase of the overall receptor RNA level occurring in ripening tomato (Lashbrook et al., 1998; Tieman and Klee, 1999) is seen as the natural response to increased ethylene biosynthesis, an attempt to maintain homeostasis, and a mechanism to temper the ethylene response (Klee et al., 2003).

In this paper we have demonstrated that, considering together ETR1 and ERS1, an increase in receptor transcripts occurs also in ripening peaches and apples, in association with increments in ethylene biosynthesis. Rasori et al. (2002) showed that $P p-E R S 1$ is up-regulated by propylene in mature peaches and a similar effect was observed in pear (ElSharkawy et al., 2002). The accumulation trend of Pp-ERS1 mRNA in open control 'Summer Rich' peach fruit observed in the present trial slightly differs from that reported by Rasori et al. (2002): this could be due to the different peach genotype and/or to some modified parameters used for the RT-PCR.

Our data confirm that peaches and apples differently react to 1-MCP and this may be due to specificities in ripening physiology. Besides the different effect on respiration (reduced in apples, basically unchanged in peaches), 1-MCP selectively affected ethylene biosynthesis and ethylene receptor gene expression in the two fruit types. In apple, 1-MCP greatly reduced $M d$-ERSI expression and a marked decrease of Md-ETRI was also present starting from a few hours after the end of the treatment. One remarkable effect has also been exerted on ACS gene expression that is strongly downregulated, confirming data recently reported by Wakasa et al. (2006) with the same cultivar. The same effect, prolonged for several days after 1-MCP treatment, was found on ACO. This down regulating effect is coupled to a block of ethylene production. Thus, it appears that in apple fruit, the presence of 1-MCP induces a general decrease and/or inhibition of parameters related to ethylene synthesis and perception.

The behaviour of peaches appears markedly different from apple, confirming that the 1-MCP ability in delaying ripening is restricted to a few hours after treatment. By comparing 1-MCP treated and sealed control fruit, similar Pp-ETRI and $P p$-ERS 1 transcript accumulation patterns were detected. The marked difference observed in Pp-ERS1 transcript accumulation between open control fruit and the two sealed samples might be imputed to some physiological effects of $\mathrm{CO}_{2}$ accumulation. Interestingly, some ethylene was produced from 1-MCP treated peaches at the end of the incubation period and an increased ethylene production was detected in the same fruit at the last sampling date. This is in agreement with previous data of Dong et al. (2001), Rasori et al. (2002) and Ziliotto et al. (2003) that showed an enhanced ethylene biosynthesis 
in the post-treatment phase of 1-MCP treated peach or nectarine fruit. Differently from apples, ACS and ACO transcript accumulations were not consistently affected in peaches, confirming previous results (Dong et al., 2001). The same authors and Ziliotto et al. (2003) showed that polygalacturonase (PG) mRNA accumulation, an ethylene-regulated process, did not differ between control and 1-MCP treated nectarines in the post-treatment phase. These data would support the hypothesis of a limited effect of 1-MCP on ethylene-responsive genes in Prunus persica ripening fruit.

Analogously to what has been observed in pear (ElSharkawy et al., 2002), in both apple and peach fruit, CTR expression showed an initial constitutive expression followed by some increase during late ripening, indicating that it may play a regulatory role in ethylene-dependent events as reported in ripening tomato (Leclercq et al., 2002). In both pear and tomato, CTR 1 expression was enhanced by ethylene (or propylene) treatments. Besides the different effect of 1MCP on Pp-CTRI and Md-CTRI transcript accumulation, a noticeable difference between peach and apple is represented by the amount of CTR transcripts detected via quantitative RT-PCR. In apples, the level of specific transcripts was higher than that of peaches by a $10^{2}$ factor.

It has been postulated that 1-MCP binds permanently to receptors present at the time of treatment and that the lack of ripening probably indicates that receptors are not regenerated (Blankenship and Dole, 2003). This could be the case with apples in which Md-ERSI expression is down-regulated by $1-\mathrm{MCP}$ treatment. In addition, it must be considered that ethylene remains undetectable in 1-MCP apples for many days following the application of the chemical. Thus, if we assume that the observed increase in ethylene receptors in accord with the ethylene climacteric rise tempers the ethylene response, the strong 1-MCP-induced inhibition of ethylene biosynthesis in apple could be responsible for the reduced expression patterns of $M d$-ETRI and Md-ERS1 genes. In pear, 1-MCP is effective in reducing ethylene production and Pc-ETRIa and Pc-ERSIa transcript accumulation (ElSharkawy et al., 2002). Assuming that receptor mRNA levels mirror protein levels, as reported for the NR gene in tomato (Klee et al., 2003), it might be hypothesized that, following 1-MCP binding to ethylene receptors in pre-climacteric apples, autocatalytic ethylene biosynthesis is blocked and, in turn, the ethylene-dependent synthesis of receptors is strongly reduced. In the presence of the pre-existing ethylene receptors occupied by $1-\mathrm{MCP}$, and with reduced receptor regeneration and an inhibition of ethylene biosynthesis, the ripening process of apple fruit is strongly delayed.

On the other hand, in peach, 1-MCP appears ineffective in altering the transcript accumulation pattern of $P p-E T R I$ and $P p$-ERS1 whose expression level remains similar to that of fruit maintained in the same environmental conditions (sealed control fruit). When compared with open control fruit, the reduction of $P p$-ERS 1 transcript accumulation of both 1-MCP treated and sealed control fruit might be imputed to $\mathrm{CO}_{2}$, which in tomato, has been shown to be effective in block- ing the expression of ripening-associated genes (Rothan et al., 1997). Whether Pp-ERS1 is actually one of these $\mathrm{CO}_{2}-$ regulated genes or not remains to be elucidated.

The different effect of 1-MCP on peaches and apples might be related to differences in terms of ethylene receptor expression patterns and/or some altered mechanisms downstream of the receptors. O'Malley et al. (2005) recently reported that, in Arabidopsis, there is a correlation between total functional binding sites and total ethylene receptor mRNA abundance. According to these findings and assuming that there is a correspondence between message and protein levels, the different mRNA abundance of the two ethylene receptor isoforms (ETR1, in particular) in apples and peaches might represent one factor responsible for the variable response of these fruit to ethylene and ethylene antagonists as 1-MCP. It has been postulated that, in Arabidopsis, ethylene receptor isoforms have different binding activity for CTR1 (Guo and Ecker, 2004), and as a consequence, a different role in ethylene signalling. With regard to CTR1, it must be stressed that the abundance of specific transcripts appears much higher (a factor of $10^{2}$ ) in apples than in peaches. Whether this markedly different amount of CTR 1 mRNA has a role in modulating ethylene-related responses in the two considered varieties remains an open question. A further control of receptors via alternative splicing and truncated forms, as reported in peach (Bassett et al., 2002; Rasori et al., 2002), is hypothesized and the consequent different association/dissociation of CTR1 with them may represent an important regulatory factor in the ethylene transduction pathway.

Taken together, these data indicate that in the apple and peach varieties used here, a marked difference in terms of total functional binding sites and receptor output is present. In order to validate these hypotheses, the other members of the apple and peach ethylene receptor family should be isolated, possibly quantified (in terms of both transcript and protein levels), and studied in their expression patterns, ethylene binding ability, and downstream (CTR, EIN2) signalling capacity of the ethylene signalling system.

\section{Acknowledgements}

Authors wish to thank Prof. Angelo Ramina for critically reading the manuscript. This work has been financially supported by AgroFresh.

\section{References}

Adams-Phillips, L., Barry, C., Kannan, P., Leclercq, J., Bouzayen, M., Giovannoni, J., 2004. Evidence that CTR1-mediated ethylene signal transduction in tomato is encoded by a multigene family whose members display distinct regulatory features. Plant Mol. Biol. 54, 387-404.

Atkinson, R.G., Bolitho, K.M., Wright, M.A., Iturriagagitia-Bueno, T., Reid, S.J., Ross, G.S., 1998. Apple ACC-oxidase and polygalacturonase: ripening-specific gene expression and promoter analysis in transgenic tomato. Plant Mol. Biol. 38, 449-460. 
Bai, J.H., Baldwin, E.A., Goodner, K.L., Mattheis, J.P., Brecht, J.K., 2005. Response of four apple cultivars to 1-methylcyclopropene treatment and controlled atmosphere storage. HortScience 40, 1534-1538.

Bassett, C.L., Artlip, T.S., Callahan, A.M., 2002. Characterization of the peach homologue of the ethylene receptor, PpETR1, reveals some unusual features regarding transcript processing. Planta 215, 679-688.

Blankenship, S.M., Dole, J.M., 2003. 1-Methylcyclopropene: a review. Postharvest Biol. Technol. 28, 1-25.

Bleecker, A.B., 1999. Ethylene perception and signaling: an evolutionary perspective. Trends Plant Sci. 4, 269-274.

Bleecker, A.B., Kende, H., 2000. Ethylene: a gaseous signal molecule in plants. Annu. Rev. Cell Dev. Biol. 16, 1-18.

Bonghi, C., Ramina, A., Ruperti, B., Vidrih, R., Tonutti, P., 1999. Peach fruit ripening and quality in relation to picking time, and hypoxic and high $\mathrm{CO}_{2}$ short-term postharvest treatments. Postharvest Biol. Technol. 16, 213-222.

Cecchetti, V., Pomponi, M., Altamura, M.M., Pezzotti, M., Marsilio, S., D’Angeli, S., Tornielli, G.B., Costantino, P., Cardarelli, M., 2004. Expression of rolB in tobacco flowers affects the coordinated processes of anther dehiscence and style elongation. Plant J. 38, 512-525.

Chang, C., Stadler, R., 2001. Ethylene hormone receptor action in Arabidopsis. Bioessays 23, 619-627.

Dal Cin, V., Danesin, M., Boschetti, A., Dorigoni, A., Ramina, A., 2005a. Ethylene biosynthesis and perception in apple fruitlet abscission (Malus domestica L Borkh). J. Exp. Bot. 56, 2995-3005.

Dal Cin, V., Danesin, M., Rizzini, F.M., Ramina, A., 2005b. RNA extraction from plant tissues: the use of calcium to precipitate contaminating pectic sugars. Mol. Biotechnol. 31, 113-120.

Dong, L., Zhou, H.W., Sonego, L., Lers, A., Lurie, S., 2001. Ethylene involvement in the cold storage disorder of 'Flavortop' nectarine. Postharvest Biol. Technol. 23, 105-115.

El-Sharkawy, I., Jones, B., Li, G., Lelievre, J.M., Pech, J.C., Latché, A., 2002. Isolation and charcterization of four ethylene perception elements and their expression during ripening in pears (Pyrus communis L.) with/without cold requirements. J. Exp. Bot. 54, 1615-1625.

Fan, X., Mattheis, J.P., 2002. Impact of 1-methylcyclopropene and methyl jasmonate on apple volatile production. J. Agric. Food Chem. 47, $2847-2853$.

Fan, X., Argenta, L., Mattheis, J.P., 2002. Interactive effects of 1-MCP and temperature on 'Elberta' peach quality. HortScience 37, 134-138.

Guo, H., Ecker, J.R., 2004. The ethylene signalling pathway: new insights. Curr. Opin. Plant Biol. 7, 40-49.

Huang, Y., Li, H., Hutchison, C.E., Laskey, J., Kieber, J.J., 2003. Biochemical and functional analysis of CTR1, a protein kinase that negatively regulates ethylene signalling in Arabidopsis. Plant J. 33, 221233.

Jiang, Y., Joyce, D.C., 2002. 1-Methylcyclopropene treatment effects on intact and fresh-cut apple. J. Hort. Sci. Biotechnol. 77, 19-21.

Kader, A.A., 1985. A summary of CA requirements and recommendations for fruit other than pome fruit. In: S.M., Blankenship (Eds.), Controlled Atmospheres for Storage and Transport of Perishable Agricultural Commodities. Proceedings of the Fourth National Controlled Atmosphere Research Conference. Raleigh, NC, July 23-26, pp. 445-492.

Kenneth, J.L., Thomas, D.S., 2001. Analysis of relative gene expression data using real-time quantitative PCR and the $2^{-\Delta \Delta C T}$ method. Methods 25 , $402-408$.

Kieber, J.J., Rothenberg, M., Roman, G., Feldman, K.A., Ecker, J.R., 1993. CTR1, a negative regulator of the ethylene response pathway in Arabidopsis, encodes a member of the Raf family of protein kinase. Cell 72 , 427-441.

Klee, H., Tieman, D., Ciardi, J., Taylor, M., 2003. Regulation of ethylene responses by control of receptor levels. In: Vendrell, M., Klee, H., Pech,
J.C., Romojaro, F. (Eds.), Biology and Biotechnology of the Plant hormone Ethylene III. IOS Press, pp. 193-197.

Klee, H., Tieman, D., 2002. The tomato ethylene receptor gene family: form and function. Physiol. Plant. 115, 336-341.

Lashbrook, C., Tieman, D., Klee, H., 1998. Differential regulation of the tomato ETR gene family throughout plant development. Plant J. 15, 243-252.

Leclercq, J., Adams-Phillips, L.C., Zegzouti, H., Jones, B., Latché, A., Giovannoni, J., Pech, J.C., Bouzayen, M., 2002. LeCTR1, a tomato CTRI-like gene, demonstrates ethylene signaling ability in Arabidopsis and novel expression patterns in tomato. Plant Physiol. 130, 1132-1142.

Liguori, G., Weskler, A., Zuthai, Y., Lurie, S., Kosto, I., 2004. Effect of 1methylcyclopropene on ripening of melting flesh peaches and nectarines. Postharvest Biol. Technol. 31, 263-268.

Mathooko, F.M., Tsunasima, Y., Owino, W., Kubo, Y., Inaba, A., 2001. Regulation of genes encoding ethylene biosynthesis in peach fruit by carbon dioxide and 1-methylcyclopropene. Postharvest Biol. Technol. $21,265-281$.

O'Malley, R.C., Rodriguez, F.I., Esch, J.J., Binder, B.M., O'Donnell, P., Klee, H.J., Bleecker, A.B., 2005. Ethylene-binding activity, gene expression levels, and receptor system output for ethylene receptor family members from Arabidopsis and tomato. Plant J. 41, 651-659.

Rasori, A., Ruperti, B., Bonghi, C., Tonutti, P., Ramina, A., 2002. Characterization of two putative ethylene receptors genes expressed during peach fruit development and abscission. J. Exp. Bot. 53, 2333-2339.

Rosenfield, C.L., Kiss, E., Hrazdina, G., 1996. MdACS-2 (accession no. U73815) and MdACS-3 (accession no. U73186) Two new 1aminocyclopropane-1-carboxylate synthases in ripening apple fruits. Plant Physiol. 112, 1735-1736.

Rothan, C., Duret, S., Chevallier, C., Raymond, P., 1997. Suppression of ripening-associated gene expression in tomato fruits subjected to a high $\mathrm{CO}_{2}$ concentration. Plant Physiol. 114, 255-263.

Ruperti, B., Bonghi, C., Rasori, A., Ramina, A., Tonutti, P., 2001. Characterization and expression of two members of the peach 1aminocyclopropane-1-carboxylate oxidase gene family. Physiol. Plant. 111, 336-344.

Sambrook, J., Fritsch, E.F., Maniatis, T., 1989. Molecular Cloning: A Laboratory Manual. Cold Spring Harbor Laboratory, New York, NY.

Sisler, E.C., Serek, M., 1997. Inhibitors of ethylene responses in plants at the receptor level: recent developments. Physiol. Plant. 100, 577-582.

Sunako, T., Sakuraba, W., Senda, M., Akada, S., Ishikawa, R., Niizeki, M., Harada, T., 1999. An allele of the ripening specific 1aminocyclopropane-1-carboxylic acid synthase gene (ACS1) in apple fruit with a long storage life. Plant Physiol. 119, 1297-1303.

Tieman, D., Klee, H., 1999. Differential expression of two novel members of the tomato ethylene receptor family. Plant Physiol. 120, 165-172.

Tonutti, P., Bonghi, C., Ruperti, B., Tornielli, G.B., Ramina, A., 1997. Ethylene evolution and 1-aminocyclopropane-1-carboxylate oxidase gene expression during early development and ripening of peach fruit. J. Am. Soc. Hort. Sci. 122, 642-647.

Wakasa, Y., Kudo, H., Ishikawa, R., Akada, S., Senda, M., Niizeki, M., Harada, T., 2006. Low expression of an endopolygalacturonase gene in apple fruit with long-term storage potential. Postharvest Biol. Technol. 39, 193-198.

Watkins, C.B., Nock, J.F., Whitaker, B.D., 2000. Responses of early, mid and late season apple cultivars to postharvest application of 1methylcyclopropene (1-MCP) under air and controlled atmosphere storage conditions. Postharvest Biol. Technol. 19, 17-32.

Ziliotto, F., Botton, A., Bonghi, C., Tonutti, P., 2003. Effect of 1-MCP on nectarine fruit postharvest physiology. In: Vendrell, M., Klee, H., Pech, J.C., Romojaro, F. (Eds.), Biology and Biotechnology of the Plant hormone Ethylene III. IOS Press, pp. 457-458. 